\title{
AS EXPECTATIVAS ESCATOLÓGICAS NA(S) FILOSOFIA(S) DA HISTÓRIA DA IGREJA ASSEMBLEIA DE DEUS NO BRASIL
}

\author{
ESCHATOLOGICAL EXPECTATIONS IN THE HISTORICAL PHYLOSOPHIES OF THE \\ ASSEMBLEIA DE DEUS NO BRASIL CHURCH
}

Diogo da Silva Roiz ${ }^{1}$

ROIZ, D. da S. As expectativas escatológicas na(s) filosofia(s) da história da igreja Assembleia de Deus no Brasil. Akrópolis Umuarama, v. 26, n. 2, p. 171-181, jul./dez. 2018.

DOI: 10.25110/akropolis.v26i2.7305

Resumo: Estuda-se o formato das expectativas escatológicas propagadas pelas filosofias da história construídas pela Igreja Assembleia de Deus no Brasil (Ministério de Belém) entre os anos 1970 e a primeira década do século XXI.

Palavras-chave: Escatologia; Filosofia da história; Igreja Assembleia de Deus.

ABSTRACT: Study the shape of the eschatological expectations propagated by the philosophies of history built by the Church Assembly of God in Brazil (Ministry of Belém) between the years 1970 and the first decade of the 21st century.

KEYwords: Assembly of God Church; Eschatology; Philosophy of his-

1Professor associado aos cursos de Pedatory.

gogia e de Ciências Sociais da UEMS, e dos programas de pós-graduação em Educação e do ProfHistória. Doutor em História pela UFPR, onde também concluiu estágio de pós-doutorado em 2015. E-mail: diogosr@ uems.br 
A proximidade das comemorações dos cem anos de fundação da Igreja Assembleia de Deus (Ministério de Belém) no Brasil suscita reflexões, debates e indagações. Não apenas pela importância que a instituição religiosa alcançou ao longo do século passado no país, mas também pela peculiaridade de seus projetos, em especial, no que diz respeito ao tipo de filosofia (ou de filosofias) da História ${ }^{2}$ a eles inserida. E o propósito deste texto é justamente o de procurar, ainda que sucinta e muito genericamente, demonstrar o quadro de questões que circunstanciou a produção desta(s) filosofia(s) da história, que deram base à constituição das expectativas escatológicas da Igreja Assembleia de Deus, entre os anos 1970 e a primeira década do século $\mathrm{XXI}$.

Quando, em 1989, a queda do Muro de Berlim deflagrou a imensa crise estrutural que perfazia os projetos da esquerda no Ocidente, de por em prática um tipo de sociedade socialista, e nos anos que se seguiram ao colapso da União Soviética pareceu que iria se concretizar os diagnósticos que então se faziam sobre o socialismo, à esquerda e ao marxismo (Cf. ANDERSON, 2004) ${ }^{3}$, os neoliberais acabariam, nesse ínterim, por aplaudirem a situação, acreditando que aquele seria o momento em que a sociedade (neo)liberal, capitalista, definitivamente entraria em cena em todas as partes do planeta (Cf. HOBSBAWM, 2009). Autores como Francis Fukuyama (1992) chegaram até a definir a situação como um momento de "fim da História", por que aquele era o período em que o projeto antevisto por Hegel no século $\mathrm{XIX}^{4}$, finalmente atingia o seu ápice. Contudo, ao longo dos anos 1990 as crises periódicas da economia mundial, não somente surpreenderam os mais pessimistas dos analistas neoliberais, quanto solaparam as avaliações mais otimistas, como a de Fukuyama, indicando o quanto a História era dinâmica

\footnotetext{
2Uma filosofia da história é uma interpretação do processo histórico segundo um fim previamente estabelecido, ainda que em um tempo "futuro" não programado, nem conhecido antecipadamente, com vistas a se inquirir o "sentido" e as "leis" que diagnosticariam e proporcionariam o movimento de transformações e permanências entre as sociedades do passado e as sociedades do presente.

${ }^{3}$ Surpreendentemente, aquele também foi $\mathrm{o}$ ano em que se comemorou o Bicentenário da Revolução Francesa, justamente quando efetivamente as relações e tensões entre esquerda (jacobina) e direita (girondina), acirravam-se diante das consequências das manifestações revolucionárias, ficando a posteridade o modo como cada uma deveria se comportar e agir politicamente (Cf SCHAFF, 1995; VOVELLE, 1987, 2000).

${ }^{4}$ Para uma análise deste projeto, ver: ANDERSON, 1992, REIS, 2011.
}

e seu movimento, por mais que parecesse diagnosticável, apresentava-se consideravelmente imprevisível. A tal ponto que nos últimos anos, após os atentados terroristas de 11 de setembro de $2001^{5}$, os Estados Unidos se mostram cada vez mais frágeis às movimentações do mercado mundial (Cf. HOBSBAWM, 2007) ${ }^{6}$.

Mas, se os projetos da esquerda e da direita se encontravam em crise, valendo o mesmo para a própria definição e identidade do que fosse direita e esquerda no Ocidente (Cf. BO$\mathrm{BBIO}, 2001)$, destacadamente revelando um momento de questionamentos (que já vinham desde as primeiras décadas do século passado) sobre as filosofias seculares da história ${ }^{7}$, parece que as filosofias religiosas da história, cujo sentido do processo histórico não se encontrava sobre as sociedades humanas, entre as coisas mundanas, mas sim sobre a promessa de uma vida eterna ao lado de Deus, têm-se renovado de forma intensa entre os seus mais variados seguimentos e instituições religiosas ${ }^{8}$.

Já em meados dos anos 1970, quando se encontrava no ápice a bipolarização do mundo, entre um Ocidente capitalista e um Oriente socialista, Christopher Dawson (2010), ao interpretar as várias dinâmicas da história mundial, concluía que se a herança de Marx havia sido apropriada pela esquerda e a de Hegel pela direita, nem por isso o movimento histórico se resumia a essas duas facções políticas. Pelo contrário, havia, para ele, uma terceira, cujo movimento parecia ser mais sutil, mas nem por isso menos importante, que era empreendido pela Cristandade Ocidental, representada pela Igreja Católica. Com as devidas especificidades em sua interpretação, Eric Voegelin (2009), em análise de meados dos anos 1960, ressaltaria a importância de se estudar não somente as filosofias seculares da história, mas, antes, estas em comparação e ao lado das filosofias religiosas da história. Para ele, o "acontecimento da filosofia é um entre muitos constituintes da história, mas ele constitui a história num modo es-

${ }^{5}$ Para uma análise do contexto que desencadeou tal situação, ver: HOURANI, 2006; FROMKIN, 2008.

${ }^{6}$ Curiosamente, ao mesmo tempo em que se avolumam as críticas sobre os projetos de por em prática qualquer tipo de socialismo nas sociedades atuais, movimento talvez ainda mais intenso se volta sobre a obra de Karl Marx (1818-1883), em vista da propriedade da análise que empreendeu sobre a formação e o desenvolvimento da sociedade capitalista no Ocidente (Cf. HOBSBAWM, 2011). ${ }^{7}$ Para uma análise da questão, ver: GARDINER, 2004; CRUZ, 2007; VOEGELIN, 2009; REIS, 2011.

${ }^{8}$ Como vários estudos têm revelado, a exemplo de: MANOEL, 2004; PROENÇA, 2011; FONSECA, 2011. 
pecial, porque o ser eterno não apenas aparece no tempo através da experiência filosófica, mas ao mesmo tempo torna transparente o logos do acontecimento", isto é, faz "o campo da história visível como um campo de tensões no ser", e, por isso, "é que a experiência filosófica pode ser entendida como um acontecimento ôntico, à medida que o ser é reconhecido como o campo das tensões históricas" (VOEGELIN, 2009, p. 401). Além disso, recorrentemente são renovadas as expectativas a respeito do "fim dos tempos", no qual o retorno de Cristo é prognosticado, o que contribui para a ampliação deste tipo de análise do processo histórico, e como inquire Georges Duby (1997, p. 20):

Estou certo de que existia, ao término do Primeiro Milênio, uma espera permanente, inquieta, do fim do mundo, porque o Evangelho anuncia que Cristo voltará um dia, que os mortos ressuscitarão e que ele fará a escolha entre os bons e os maus. Todo o mundo acreditava nisso e aguardava o dia da cólera que provocaria, evidentemente, o tumulto e a destruição de todas as coisas visíveis. No Apocalipse, lia-se que, quando mil anos tivessem decorrido, Satã seria libertado de suas correntes e viria, então, o Anticristo.

Não sem razão, a promessa de garantir as graças de Deus concedeu, ao longo dos séculos, tamanho poder a Igreja, e:

Isso explica o poder extraordinário da Igreja, dos servidores de Deus na terra, pois o Estado, tal como o concebemos hoje, não existia. O direito de comandar, fazer justiça, proteger, explorar o povo dispersava-se entre vários pequenos núcleos locais. [...] O que diferencia mais claramente a civilização européia das outras é que ela é essencialmente historicizante, ela se concebe como estando em processo. O homem do Ocidente tem o sentimento de que progride em direção ao futuro e, assim, ele é muito naturalmente levado a considerar o passado. O cristianismo, que impregnou fundamentalmente a sociedade medieval, é uma religião da história. Proclama que o mundo foi criado num dado momento e que, num outro, Deus fez-se homem para salvar a humanidade. A partir disso, a história continua e é Deus quem a dirige. Para conhecer as intenções divinas é necessário, portanto, estudar o desenrolar dos acontecimentos. É isso o que pensavam os homens cultos, os intelectuais daquela época, ou seja, os membros da Igreja. Todo o saber estava em suas mãos. Um monopólio exorbitante. [...] Somente os servidores de Deus sabiam escrever e ler, e consideravam como seu dever explicar a história, de maneira a nela detectar os sinais de Deus. Estavam convencidos de que não há barreiras estanques entre o mundo real e o sobrenatural, que existem sempre passagens entre ambos e que Deus se revela naquilo que Ele criou, na natureza, mas também na maneira pela qual orientou o destino da humanidade (Id. ibid., p. 15-17).

Assim, por intermédio de várias comparações, o autor demonstrava que, ainda que o progresso material e espiritual, assim como considerar a história em processo, fosse a marca da civilização ocidental, tanto no período medieval quanto no contemporâneo, este não era totalmente linear, constante e ascendente (Cf. ROIZ, 2010) ${ }^{9}$. Por outro lado, ao demonstrar como se formava a imaginação apocalíptica, John Collins (2010) infere que por se basear em instâncias imateriais, cuja realização, de fato, não deixava de ser um mistério, amplamente amparado sobre a fé de cada indivíduo, é que a tornou tão perdurável ao longo do tempo, sendo periodicamente atualizada, revista e ampliada pelos fiéis, pelas instâncias religiosas e pelos próprios clérigos.

\footnotetext{
9á nos anos 1930 Mumford (1952) visualizava tais questões, ao indicar que: "Ao aproximar-se o ano 1000, muita gente acreditava estar chegando a seu têrmo o reinado milenário de Cristo; era o fim do mundo que se aproximava" (p. 125). Nos anos 1940 foi à vez de Henri Focillon (1881-1943), asseverar avaliação semelhante da questão, em obra publicada postumamente, e que foi resultado de seus cursos ministrados na França e nos Estados Unidos, entre os anos de 1930 e 1940, onde indicava que : "A história não é o devir hegeliano. Não se assemelha a um rio que transportasse à mesma velocidade e na mesma direcção os acontecimentos e os resíduos de acontecimentos. É até a diversidade e a desigualdade das correntes que constituem propriamente o que chamamos História. Deveríamos antes pensar numa sobreposição de camadas geológicas, diversamente inclinadas, por vezes interrompidas por fendas bruscas, e que num mesmo lugar e num mesmo momento nos permitem distinguir várias idades da Terra, de modo que cada fracção do tempo decorrido é simultaneamente passado, presente e futuro" (1977, p. 11-12). Aliás, tal perspectiva inspirará ao trabalho de Georges Duby, em meados dos anos 1960. Com a passagem de 1999 para o ano 2000, se dará ensejo a produção de várias análises sobre essa questão, tais como: DUBY, 1997; FRANCO Jr., 1999; LACEY, DANZIGER, 1999.
} 


\section{Política e filosofia ultramontana na história da Cristandade Ocidental}

Assim, não por acaso, desde a década de 1960, pelo menos, várias pesquisas deslocaram sua atenção da instância institucional das Igrejas para analisar como se formam as comunidades religiosas, isto é, não apenas estudar o discurso institucionalizado veiculado pelo líder religioso, mas também as formas como o discurso é apreendido e reelaborado pala comunidade dos fiéis. A mudança na ênfase de pesquisa de vários estudiosos do fenômeno religioso nas últimas décadas foi proporcionada pela ampliação dos objetos, problemas e abordagens vindas, fundamentalmente, com a "Nova História" francesa e com o marxismo inglês, a partir da década de 1960 (Cf. BURKE, 1992; REIS, 2003).

Mas, o desenvolvimento dessas abordagens foi propiciado, fundamentalmente, porque no interior do pensamento de esquerda uma crise ininterrupta apresentava-se sobre a base de seu projeto político, e com a queda do Muro de Berlim, em 1989, e do fim da URSS, no início dos anos 1990, os reflexos dessa crise se agravaram ainda mais para a esquerda (e, depois, também para a direita). De proporções diferentes, mas não menos importantes, são as críticas que se avolumam cada vez mais sobre o lluminismo e o Positivismo. Num tempo de questionamentos que se volta sobre todas as heranças intelectuais do passado, nem mesmo o pensamento religioso passou ileso.

Constituindo-se, desde os séculos XVIII e XIX, nos modelos mais significativos de interpretação das sociedades do passado, o(s) lluminismo(s), o(o) Positivismo(s) e o(s) Marxismo(s) ${ }^{10}$, que almejaram atingir por meio

${ }^{10}$ Assim como o marxismo e o positivismos tiveram diversos desdobramentos, na teoria e na prática, desde o século XIX, quando foram produzidos, o próprio movimento lluminista seguiu compasso semelhante. Como destaca Maria das Graças de Souza (2001), além das posturas serem diversas, em várias ocasiões também eram divergentes, umas com as outras. Para ela, enquanto Rousseau se detinha na demarcação das razões que indicavam a decadência do gênero humano, em função do declínio das tradições e das relações com o passado, voltando-se exemplarmente sobre uma interpretação e um retorno das relações que os homens tinham no passado; Condorcet descortinaria os momentos decisivos que plasmariam as épocas revolucionárias, com vistas a transformar o seu próprio presente histórico. E Voltaire, por sua vez, ao elencar os valores e as circunstâncias de que se apoiavam os grupos humanos para formarem suas civilizações, deter-se-ia sobre os motivos que desencadeariam os progressos, para planejar o futuro. Nesse sentido, ora se apoiavam no passado, ora no presente, ora no futuro, para interpretarem o processo histórico e apreenderem o seu movimento. Com isso, Rousseau vislumbraria a decadência daquela sociedade, em função das consequências de suas 'Filosofias da História' a realização de seus projetos políticos, revelaram-se, no século XX, sem a mesma força explicativa e sem a mesma capacidade de realização na 'pratica'11. $E$ isso, fundamentalmente, porque o projeto de uma sociedade globalizada e harmonizada pelas luzes, no lluminismo, de uma sociedade humanizada pelo saber científico, no Positivismo, e de uma sociedade justa e sem divisões de classes, no Marxismo, demonstraram-se ineficientes quanto ao próprio movimento histórico que veio a tornar (talvez até) irrealizáveis, na prática, cada um daqueles projetos específicos. No caso do pensamento religioso, no seu viés Católico, as perspectivas não são diferentes, já que foi o pioneiro na produção daqueles esquemas interpretativos do processo histórico. No entanto, este tem se mostrado mais eficaz ao contornar os dilemas desencadeados pelas várias críticas que foram feitas aos seus fundamentos, porque a base de suas propostas se encontrava num terreno imaterial, cuja demonstração era mais pautada sobre a fé, do que sobre uma demonstração racional, além de estar cerceado pelo mistério divino.

Para Ivan Manoel (2004), deve-se diferenciar, de imediato, que a palavra Igreja possui duas vertentes interpretativas, uma se referindo a Eklesía, que representa uma comunidade de fiéis sob a orientação de um líder religioso, e outra que diz respeito à instituição religiosa e a todas as suas hierarquias. Por outro lado, ao entender por 'filosofia da história' uma interpretação do processo histórico, a partir de um fim previamente estabelecido, embora em um tempo não determinado, quer dizer, "como demonstração de um sentido, de uma direção única e inexorável do trajeto da humanidade ao longo do tempo em direção a um fim", considerando esta "religiosa ou materialista", além de operar "com a ideia de término do processo histórico em um ponto ideal de chegada para a humanidade" (MANOEL, 2004, p. 13), que o autor procurou distinguir, no interior da filosofia católica da história, o seu projeto político, da sua interpretação

do progresso técnico e material, Voltaire efetuaria o elogio do progresso, ao evidenciar os caminhos do futuro para a civilização européia, e Condorcet daria um prognóstico ao presente, com base nas escalas de desenvolvimento e de progresso que a civilização poderia alcançar em períodos revolucionários (como o da Revolução Francesa). Veja-se também as análises de: ROUANET, 1987; KOSELLECK, 1999, 2006; HARTOG, 2003; AUERBACH, 2007; HIMMELFARB, 2011.

${ }^{11}$ Para uma discussão mais detalhada dessa questão, ver: GARDINER, 2004; DAWSON, 2010; REIS, 2011; HOBSBAWM, 2011. 
da história ${ }^{12}$.

Para esse autor, o projeto político do catolicismo conservador, no período de 1800 a 1960, desdobrou-se em três momentos: a) um primeiro que vai de Pio VII (1800-1823) a Pio IX (1846-1878) e que corresponderia à consolidação da doutrina restauradora da instituição sobre os fiéis (e por isso conservadora), em que o discurso foi o instrumento de ação, e houve um reforço da doutrina e das práticas devocionais; b) um segundo centrado no pontificado de Leão XIII (1878-1903), "que sem abandonar a doutrinação contra o mundo moderno, deu passos decisivos para o estabelecimento de uma política de intervenção" (MANOEL, 2004, p. 12) sobre a realidade; c) e um terceiro de Pio X (1903-1914) a Pio XII (1939-1958), sobre o qual a doutrina foi convertida em política e o discurso em ação, e essa "atuação se deu no sentido de se recristianizar as estruturas sociais, de dotá-las de um fundamento doutrinário católico, de tirá-las das influências malignas do racionalismo, do materialismo, do liberalismo e do socialismo", por meio de programas da Ação Católica, "que acabaram por gerar as contradições que levaram ao Concílio Vaticano II e à Teologia da Libertação" (Id. Ibid.).

O projeto político da Igreja Católica também se pautou sobre uma interpretação peculiar do processo histórico. Essa interpretação teve, para ele, sua origem no pensamento de Santo Agostinho (354-430) e São Tomás de Aquino (1225-1274), sendo que o primeiro procurou sistematizar uma crítica sobre a compreensão circular do tempo vislumbrado na Antiguidade Clássica e recorrer a uma análise linear do tempo, e o segundo veio a consolidar as bases institucionais da Igreja. Em Santo Agostinho, o tempo não é fruto de um eterno retorno como o foi para Gregos e Romanos (em menor proporção), mas é construído segundo um início e um fim. Para ele, o início era a Queda do Homem (Adão e Eva) do Paraíso e o fim seria o retorno do Homem a Deus, isto é, ao seu estado de eternidade. Nos séculos XVIII e XIX, as principais filosofias leigas da história vieram a secularizar o sentido daquela interpretação, revisando os fatos e os agentes principais do processo e definindo outros fins. Entretanto, o finalismo "que frequenta[va] as filosofias leigas da história se mostra[va] por inteiro na filosofia católica da his-

\footnotetext{
${ }^{12}$ Para uma discussão mais profunda sobre a definição e a interpretação das filosofias da história, ver: CRUZ, 2007.
}

tória, não já como um mistério a ser decifrado, mas como certeza a ser demonstrada para a tranquilidade dos fiéis e conversão dos ímpios" (Id. Ibid. p. 16). E foi justamente quanto a esse tópico, ao lugar onde deveria caminhar a humanidade, que partiram todas as criticas da reação da Igreja Católica, entre os séculos XIX e parte do XX, sobre aquelas filosofias leigas da história. Os tópicos que abrangem aquelas críticas, quer dizer, o progresso material, o moderno conceito de tempo, a condenação do conhecimento racional e a estratégia de um retorno a Idade Média, foram os tópicos analisados por Ivan Manoel em sua obra.

Não sem razão, o primeiro ponto daquela reação foi a negação católica do conceito de progresso, quando referido aos avanços materiais ${ }^{13}$. O sentido do progresso tratado por Santo Agostinho e retomado pela filosofia católica da história não se realizava no terreno mundano, mas dizia respeito a uma coexistência entre o mundo terreno e o mundo celeste, na medida em que o homem realizava o seu aprendizado em torno de uma futura redenção com Deus, em função de seu desvio inicial ${ }^{14}$. As filosofias leigas da história, por outro lado, deturparam, segundo o catolicismo conservador, aquele sentido ao definirem o progresso como uma linha de avanço em paralelo ao desenvolvimento tecnológico e material. Por terem surgido entre a Revolução Francesa e a Revolução Industrial do século XVIII, quer dizer, em um momento de transformações sociais e econômicas drásticas, aquelas filosofias leigas da história, ainda segundo o catolicismo conservador, desviaram a atenção dos homens de Deus, preferencialmente, por estabelecerem expectativas que não se confirmariam no terreno celeste, mas se concretizariam dentro da própria existência humana, o que veio a levar os homens a caírem na perdição. Além disso:

Essa ruptura opôs frontalmente a Igreja Católica aos filósofos racionalistas acerca da filosofia da história, em especial no que tange à teoria do progresso (...) [e] a Igreja Católica rejeitava a teoria laica do progresso e da perfeição humana por uma razão política, que se confundia com a questão doutrinária. (...) De um lado, os demiurgos da modernidade, para quem a Igreja Católica era uma so-

${ }^{13}$ Como pode ser facilmente aferível pela análise de autores como: LOWITH, 1991; MARRAMAO, 1995, 1997.

${ }^{14}$ Para maior detalhamento desta questão, ver: LOWITH, 1991. 
brevivente reacionária que deveria desaparecer com o que restava da Idade Média. De outro, a Igreja Católica, que identificava a modernidade e seus construtores ao Mal, qualificando-os, portanto, como seus inimigos e inimigos da humanidade (Idem, p. 43-44).

Sobre esse ponto não apenas os membros da instituição participaram daquela disputa, mas os próprios intérpretes católicos da história vieram a demonstrar os malefícios das filosofias leigas da história, ao desviarem os homens do 'verdadeiro' sentido de sua existência. O projeto do catolicismo ultramontano era o de derrubar as muralhas e extirparem os inimigos, por meio de uma intensificação da doutrina que levava: a) os homens a aceitarem e praticarem os preceitos e o ritualismo católico em sua forma romanizada; b) a repelirem o conjunto teórico e filosófico racionalista do mundo moderno; c) a aceitarem o tomismo como única filosofia válida para a humanidade; d) e a recusarem o mundo capitalista e recuperarem a feudalidade como paradigma social.

O segundo ponto da reação católica foi a não aceitação do moderno conceito de tempo, e o significado dessa reação estava ligado à transferência de funções de um tempo que era e pertencia a Deus, para um tempo racional, para o qual o homem estaria no controle. O efeito dessa mudança na compreensão do tempo, para o catolicismo conservador, era o desvio do projeto atribuído ao homem pela Igreja Católica, já que os homens se tornavam os sujeitos de suas próprias ações.

O terceiro ponto da reação católica foi a condenação do conhecimento racional, considerado causa da perdição humana. O conhecimento racional alterava o movimento histórico do projeto político do catolicismo conservador, porque refazia a qualidade do movimento, dando-lhe um outro eixo (do casal original para a teoria evolucionista), já que o seu início e o seu fim se tornavam distintos daqueles programados pela Igreja Católica. Além disso, apresentava-se como um risco aos fundamentos católicos do movimento histórico, também quanto à questão da origem humana.

Por fim, a reação do catolicismo, ao negar a sociedade moderna em todos os seus fundamentos, notou a necessidade de paralisação do movimento histórico, recorrendo à volta aos padrões medievais como bases da salvação humana. Foi na Idade Média, segundo o argumento católico, que o homem esteve mais próximo a Deus e o que fez a sociedade moderna foi desviar o caminho do homem de sua salvação ${ }^{15}$.

O trabalho de Ivan Manoel (2004), nesse sentido, contribui para se observar a complexa rede de relações que se formou entre a lgreja Católica e o movimento romântico no século XIX, ou ainda, entre 'Ela' e o nazismo no século $X X$. O seu trabalho demonstra que nas últimas décadas o conceito de progresso está em crise, assim como os atributos a ele recorrentes pelas filosofias leigas e católicas da história, e que as modernas correntes historiográficas, ao negarem o conceito de progresso, se pautaram sobre um projeto político que se aproxima da interpretação das sociedades do passado, elaborada na Antiguidade.

\section{2. "Sob as graças de Deus": a(s) filosofia(s) da história da Igreja Assembleia de Deus}

Destarte, como a Igreja Católica tem procurado responder aos desafios da contemporaneidade, com as devidas especificidades, as igrejas evangélicas no Brasil não têm feito diferente, ao procurarem ampliar o seu rebanho, com a justificativa de que o seu projeto para a salvação dos fiéis, além de ser mais ancorado na Bíblia, também constituía a mais viável aliança dos homens com Deus. Para Wander Proença (2011), tal expectativa, ao lado de um discurso carismático, voltado para a afirmação do sucesso dos homens e das mulheres, no mundo terreno e no celestial, foi uma das razões de a Igreja Universal do Reino de Deus ter ido de pouco mais de uma dezena de ouvintes em 1977, quando foi fundada, para mais de três miIhões de adeptos em 2007. Por sua vez, desde a sua fundação, a Igreja Assembleia de Deus (Ministério de Belém), tem procurado converter seus fiéis, pautando-se sob certos diagnósticos a respeito da salvação ${ }^{16}$, e, não por acaso, os articulando numa (talvez fosse mais adequado dizer várias) filosofia(s) da história, cuja expectativa escatológica é um de seus desdobramentos mais nítido. Isto é, sob um discurso escatológico emitido pelos líderes religiosos, com vistas a fomentar a credulidade dos fiéis para a busca

\footnotetext{
${ }^{15}$ Veja-se também a instigante análise de: MARRAMAO, 1997.

${ }^{16}$ Dadas as características deste texto, não temos como detalhar a fundação da instituição no Brasil. Para uma discussão detalhada do tema, ver: FONSECA, ROIZ, 2011; FONSECA, 2011.
} 
da salvação de suas almas imortais, ao lado da própria expectativa dos fiéis a respeito de uma vida post-mortem no reino de Deus.

Para empreender tal programa não foram poucos os empecilhos enfrentados pela instituição, cujas doutrinas precaviam os fiéis quanto aos males causados pelos meios de comunicação de massa, em especial, a televisão (FONSECA; ROIZ, 2009). De forma semelhante, esses deveriam estar atentos aos vários $\mathrm{e}$ sedutores discursos proferidos pela esquerda, cuja orientação se baseava em um ateu que viveu no século XIX (Karl Marx), contrário à Igreja de Deus, e, portanto, a salvação dos fiéis (FONSECA; ROIZ, 2010). Nesse sentido, atentos aos males do mundo representados pelo mau uso da tecnologia, em função dos discursos e imagens por ela veiculados, ao lado das propagandas de uma esquerda pagã, porque contrária aos planos de Deus, é que a Igreja Assembleia de Deus procurava justificar todo seu programa de "usos e costumes" perante seus fiéis.

Desnecessário frisar que uma coisa era a teoria, e outra era a prática, ou melhor, a forma como eram veiculadas as representações da Igreja estavam sempre em tensão com as práticas empreendidas pelos fiéis (FONSECA 2011). Daí a necessidade de acirrar o controle, por meio das doutrinas de "usos e costumes"; daí também a necessidade de demonstrar a importância da salvação. Os anos de 1990 foram, por isso, de tamanha importância para a instituição, por marcar a tentativa de empreender um projeto extremamente audacioso de arregimentar fiéis para sua causa (FONSECA; ROIZ, 2011), e, ao fim e ao cabo, acabar por rever todo o corpo de suas doutrinas, em função do alcance, então avaliado como restrito, do projeto empreendido na chamada "década da colheita" (FONSECA; ROIZ, 2011).

Para demonstrar, ainda que sucintamente, o quanto essas orientações estavam pautadas num projeto escatológico de salvação dos fiéis, e, no limite, dando certo sentido e direção as ações empreendidas pela humanidade em direção a uma dada finalidade, pautamo-nos nos escritos institucionais, de cunho doutrinário, publicados no jornal Mensageiro da Paz, entre 1919 e 2004. E dando especial atenção aos três volumes editados por Antônio Pereira de Mesquita, com os artigos que marcaram a história e a teologia do Movimento Pentecostal no Brasil. A edição dos textos ficou a cargo da Casa Publi- cadora das Assembleias de Deus (CPAD), que é a imprensa oficial da instituição religiosa no país. Nossa análise se deteve com maior atenção ao período dos anos 1970 até o início dos anos 2000.

Não sem outra razão, atento a todos os ensejos que causaram a entrada no ano 2000 , aos mais variados segmentos religiosos no mundo, Ival Teodoro, em julho daquele ano, no artigo "Contextualizando a crise hodierna", veiculado no Mensageiro da Paz, alertava que tudo "o que vemos até o presente é o prenúncio da volta de Cristo", pois, em "todos os tempos Deus vem advertindo o mundo através de vários meios" e usou "a Bíblia, os anjos, deu visões aos profetas e ultimamente continua falando bem alto e claro por meio das crises e dificuldades", para preparar os fiéis de que a vinda "de Cristo se aproxima", tendo em vista que todos "os sinais estão se cumprindo" e a "crise atual é um aviso da sua iminente volta" (MESQUITA, 2004, v. 3, p. 205).

Evidentemente, se todos os sentidos simbólicos antevistos a esse tipo de data, como já havia ocorrido com a passagem do ano 1000 e, com as devidas peculiaridades, também do ano 2000 (DUBY, 1997), ainda que favorecesse a produção deste tipo de alerta e de perspectiva finalista. Convém, de imediato, destacar que tais prenúncios estiveram sendo, periodicamente, recolocados pelos membros da instituição religiosa, desde a sua fundação no Brasil. $\mathrm{Na}$ primeira quinzena de Abril de 1931, Gunnar Vingren, no mesmo periódico, alertava aos fiéis que O senhor vem!, e que a "realidade é que Jesus vem", pois, as "Escrituras assim o dizem" (MESQUITA, 2004, v. 1, p. 84). Na segunda quinzena de Outubro de 1937, Bruno Skolimowsky, ao definir que $O$ fim vem, alertava que vem "chegando, sem dúvida, a grande apostasia predita pelo apóstolo Paulo" (MESQUITA, 2004, v. 1, p. 167), e desde que redimidos sob o sangue de Cristo, o povo estaria salvo com a volta do Salvador.

Com a mesma perspectiva, Antonio Gilberto, em Junho de 1957, alertava aos fiéis que Negociai até que eu venha, pois, "Deus usa homens para falar a homens, portanto é a nós [...] que foi entregue a tarefa de evangelizar o mundo" (MESQUITA, 2004, v. 2, p. 67), donde todo homem deve agir de acordo com seus dons, para efetuar o melhor exercício possível de suas ações. E, não por acaso, Rodrigo Silva Santana, em 1974, perscrutava Agora ou nunca mais, haja vista que vivemos "numa época em que não 
se pode perder nem sequer um minuto", pois, o "tempo, nestes dias de evolução e progresso, tem que ser aproveitado, segundo por segundo". A "verdade é que em todos os setores da vida humana, os que possuem parcelas de responsabilidade não podem estar indiferentes aos mais diversos problemas que ameaçam de maneira desastrosa a vida da humanidade". Contudo, "creio que esta gloriosa oportunidade que Deus está nos concedendo é para que a lgreja cumpra a sua responsabilidade", isto é, "realizamos agora ou nunca mais, não há tempo a perder, a necessidade é urgente", visto que o "mal ameaça o mundo e só o Evangelho é capaz de deter a força do mal, porque é o poder de Deus", e a "Igreja está de posse deste poder para resolver o cruciante problema que oprime o mundo" (MESQUITA, 2004, v. 2, p. 171).

Com os desdobramentos da Resolução de Santo André, de 1975, e com base nas avaliações das ações empreendidas durante a "década da colheita" nos anos 1990, cujos resultados ficaram muito aquém ao que esperava a instituição religiosa, muito embora não fossem irrisórios os frutos alcançados por aquele labor (FONSECA; ROIZ, 2011), parece que mais se intensificava o programa institucional e as atitudes finalistas, veiculadas pela imprensa periódica da Igreja Assembleia de Deus no Brasil.

Conforme indica Alcino Lopes Toledo, em Março de 2001, no seu artigo A ciência se multiplicará, como sendo um alerta de que esta "prerrogativa" já anunciada pela Bíblia "é também um dos anúncios da volta de Cristo para buscar a Igreja, e também um dos sinais que prova a [...] proximidade do Arrebatamento" (MESQUITA, 2004, p. 215). Em Fevereiro de 2002, foi a vez de Paulo Ferreira prognosticar os Sinais da segunda vinda, pois, depois "da tempestade internacional desencadeada pela destruição do Word Trade Center e parte do Pentágono, nos Estados Unidos, devemos prestar atenção a outros acontecimentos que para muitos vão passando despercebidos", tais como: "a entrada em circulação do Euro, moeda única da Comunidade Econômica Européia (prenúncio de um governo mundial único), o aumento da violência na Palestina, o conflito Índia-Paquistão, a crise Argentina, o recrudescimento do fanatismo político-religioso, o crescimento da violência urbana e os dados sobre o aumento da pobreza, entre outros" (MESQUITA, 2004, p. 229) fatos importantes, que não deveriam ficar despercebi- dos, já que estariam articulados ao projeto divino de redenção dos homens perante o Criador. Não sem razão, os fiéis deveriam estar permanentemente alertas para os sinais da segunda vinda de Cristo.

Em Junho daquele ano, Torrence Johnson, ao perscrutar Por que Jesus ainda não voltou?, deixava claro aos fiéis que só Deus "sabe quando a Vinda de seu Filho vai se encaixar na História e na eternidade" (MESQUITA, 2004, p. 238). Ao avaliar a Bíblia e a crise econômica mundial, em Setembro daquele ano, Dionísio lgnácio Rocha asseveraria que a "meu ver, a Igreja está mais para a primavera" e só "depois dessa estação chegará o verão” (MESQUITA, 2004, p. 251), dando ensejo a segunda vinda de Cristo, para a redenção dos fiéis. Para Edmar Cunha Barcelos, em Fevereiro de 2003, Fome, pestes e conflitos eram outros sinais que anteviam o retorno de Cristo, pois, as Escrituras já indicavam todos os sinais que dariam ensejo ao seu retorno (MESQUITA, 2004, p. 260-61). Com isso, a Igreja deveria estar constantemente alerta às indicações dos sinais, como prenúncio ao retorno de Cristo, conforme alertava Richard Hoover, em Os sinais e a posição da Igreja (MESQUITA, 2004, p. 264-66).

Não por acaso, em Agosto de 2003, Joel Freire indicava que deveriam ser revistas as nossas interpretações escatológicas, pois, em se "tratando de Escatologia, do muito que é discutido e publicado, pouca coisa é exata; muita coisa é interpretação e alguma coisa é pura especulação" (MESQUITA, 2004, p. 273). Entre essa e outras razões, é que para Francisco Eurico, em Setembro daquele ano, fazia com que $O$ mundo est[ivesse] à procura de um líder, pois, a "história mostra que a unidade em torno de um líder vem sendo ensaiada no decorrer dos tempos", e quando "Deus é deixado de lado e o orgulho nacional predomina, incontáveis exércitos têm marchado, matado e conquistado a fim de edificar um império para algum tirano" (MESQUITA, 2004, p. 277-78). Assim, para José Antônio dos Santos, em Novembro daquele ano, o culto aos anjos não deixava de ser uma apostasia sobre o tempo do fim; quer dizer, pelo "relato sagrado, entendemos que os anjos são seres espirituais criados por Deus e que, apesar da rebelião liderada pelo querubim ungido, mantiveram-se fiéis a Deus no seu pacto e aliança", aliás, somente "um terço das hostes angelicais deixaram-se seduzir pelo Inimigo de Deus", e em "virtude des- 
sa rebelião, os anjos caídos procuram seduzir pessoas incautas para que sejam adorados e cultuados"; mas, os "verdadeiros anjos de Deus recusam qualquer tipo de adoração" (MESQUITA, 2004, p. 279).

Assim sintetizadas as propostas de avaliação das atitudes humanas, mediante a definição de uma finalidade para a humanidade, a Igreja Assembleia de Deus, Ministério de Belém, ao lado de outras instituições religiosas, vem procurando reformular e renovar a(s) sua(s) filosofia(s) da história, para arregimentar o maior número possível de fiéis em prol de suas causas, justificadas com base na salvação, isto é, da redenção dos homens diante de seu Criador.

\section{CONSIDERAÇÕES FINAIS}

Vimos ao longo deste texto, portanto, que muito embora as filosofias seculares da história estejam sendo cada vez mais descartadas, pelo fato de não concretizarem seus projetos políticos na prática; no caso das filosofias religiosas da história, por estarem pautadas sobre o mistério divino, ao contrário daquelas, estão conseguindo se renovar e reformular suas filosofias, assim como seus projetos políticos, ao darem novos sentidos à finalidade das atitudes humanas, mediante a conquista ou não das graças de Deus, no reino dos céus ${ }^{17}$.

No caso da Igreja Assembleia de Deus, tais propostas, ao contrário de estarem sendo só agora revistas, já faziam parte de seu repertório discursivo desde sua fundação no Brasil, no início do século passado. $E$ os ensejos causados pela passagem do ano 2000 , apenas fizeram proliferar ainda mais os diagnósticos e perspectivas sobre o fim dos dias e o retorno de Cristo.

Portanto, se a instituição soube alterar suas doutrinas e atitudes quanto aos "usos e costumes", de acordo com as necessidades forjadas pelos diferentes contextos, nem por isso esta deixou de ter certo padrão de análise dos fatos e das coisas, sugerindo um sentido para as ações humanas, de modo que os homens e as mulheres, ao se voltarem para Deus viessem a alcançar a redenção de seus pecados na Terra,

\footnotetext{
${ }^{17}$ Ainda que consideremos a crise causada sobre a Igreja Católica após os atos de pedofilia e estupros causados por padres em várias partes do mundo, nem por isso o discurso messiânico da igreja veio a se tornar menos operacional. O mesmo tem ocorrido com as várias igrejas evangélicas no Brasil, apesar das periódicas denúncias de desvio de verbas, arrecadadas com os dízimos, práticas inadequadas e usos indevidos das escrituras sagradas.
}

para conquistarem a vida eterna no Paraíso e ao lado do Senhor. Contudo, ainda que essa filosofia da história - por definir como deveriam ser interpretados os processos históricos, de modo a fornecer um sentido para as atitudes humanas, com vistas a alcançar certa finalidade num futuro indeterminado -, mantivesse uma regularidade relativa ao longo do tempo, esta não formaria uma única unidade, mas sim uma pluralidade de sentidos, dada a riqueza de suas narrativas e interpretações das escrituras, que vieram a Ihe fornecer certa perpetuação e conseguir se reproduzir, sob novas formas, de um momento para o outro.

\section{REFERÊNCIAS}

ANDERSON, P. Considerações sobre o marxismo ocidental. São Paulo: Boitempo Editorial, 2004.

. O fim da história: de Hegel a Fukuyama. Rio de Janeiro: Jorge Zahar Editor, 1992.

AUERBACH, E. Mimesis: a representação da realidade na literatura ocidental. 5. ed. São Paulo: Ed. Perspectiva, 2007.

BOBBIO, N. Direita e esquerda. Razões e significados de uma distinção política. Tradução de Marco Aurélio Nogueira - $2^{\mathrm{a}}$ edição revista e ampliada - São Paulo: Editora UNESP, 2001.

BURKE, P. (org.) A escrita da história. Novas perspectivas. Tradução de Magda Lopes $-4^{a}$ reimpressão - São Paulo: Editora UNESP, 1992.

COLLINS, J. J. A imaginação apocalíptica: uma introdução à literatura apocalíptica judaica. São Paulo: Paulus, 2010.

CRUZ, J. C. Filosofia da História. Tradução de Fernando Marquezini. São Paulo: Instituto Brasileiro de Filosofia e Ciência "Raimundo Lúlio", 2007.

DAWSON, C. Dinâmicas da História do Mundo. São Paulo: É Realizações, 2010.

DUBY. G. Ano 1000, ano 2000: na pista de nossos medos. Tradução de Eugênio Michel da Silva. São Paulo: Editora UNESP, 1997.

FONSECA, A. D. As fronteiras da leitura: im- 
prensa e práticas de leitura na Igreja Assembléia de Deus. Dissertação de mestrado em História, UFGD, 2011.

FONSECA, A. D.; ROIZ, D. S. Década da colheita: uma reflexão sobre as ações doutrinárias na Igreja Assembléia de Deus na década de 1990.

Revista Regional de História, v. 16, n. 1, 2011, p. 235-270.

Religión e imperialismo: representaciones del marxismo en la revista Lições Bíblicas de la Iglesia Asamblea de Dios de Brasil (19801990). Cultura y Religión (En línea), v. IV, 2010, p. 55-69.

As representações da Igreja Assembléia de Deus sobre a televisão entre 1960 e 2000. Revista Brasileira de História das Religiões, v. II, 2009, p. 185-205.

FOCILLON, H. O ano mil. Tradução de Adelino dos Santos Rodrigues. Portugal: Edições Mandacaru, 1977.

FRANCO Jr., H. O ano 1000 - Tempo de medo ou esperança? São Paulo: Companhia das Letras, 1999.

FROMKIN, D. Paz e guerra no Oriente Médio: a queda do Império Otomano e a criação do Oriente Médio moderno. Rio de Janeiro: Contraponto, 2008.

FUKUYAMA, F. O fim da história e o último homem. Rio de Janeiro: Rocco, 1992.

GARDINER, P. Teorias da História. Trad. Vítor Matos e Sá. $5^{\text {a }}$ Ed. Lisboa: Fundação Calouste Gulbenkian, 2004.

HARTOG, F. Régimes d'historicité. Présentisme et expériences du temps. Paris: Le Seuil, 2003.

Evidência da História: o que os historiadores vêem. Tradução de Guilherme João de Freitas Teixeira; Jaime Clasen. Belo Horizonte: Autêntica Editora, 2011.

HIMMELFARB, G. Os caminhos para a modernidade: os lluminismos Britânico, Francês e Americano. São Paulo: É Realizações, 2011.

HOBSBAWM, E. J. Globalização, democracia e terrorismo. São Paulo: Companhia das Letras, 2007.

Era dos extremos: o breve século $X X$ (1914-1991). Tradução de Marcos Santarrita. $2^{a}$ Edição, 40ª Reimpressão. São Paulo: Companhia das Letras, 2009.

Como mudar o mundo: Marx e o marxismo. Tradução de Donaldson M. Garschagen. São Paulo: Companhia das Letras, 2011.

HOURANI, A. B. Uma história dos povos árabes. São Paulo: Companhia das Letras, 2006.

KOSELLECK, R. Futuro passado: contribuição à semântica dos tempos históricos. Rio de Janeiro: Contraponto; Editora PUC - Rio, 2006.

Crítica e crise: contribuição à patogênese do mundo burguês. Rio de Janeiro: Contraponto; Eduerj, 1999.

LACEY, R.; DANZIGER, D. O ano 1000: a vida no final do primeiro milênio. Tradução de Alfredo Barcellos Pinheiro de Lemos. Rio de Janeiro: Campus, 1999.

LOWITH, K. O sentido na História: implicações teológicas das filosofias da história. Portugal: Edições 70, 1991.

MANOEL, I. A. O pêndulo da História. Tempo e eternidade no pensamento Católico (18001960). Maringá: Eduem, 2004.

MARRAMAO, G. Poder e secularização: as categorias do tempo. São Paulo: Editora UNESP, 1995.

Céu e terra: genealogia da secularização. São Paulo: Editora UNESP, 1997.

MESQUITA, A. P. (org.) Mensageiro da paz: os artigos que marcaram a história e a teologia do Movimento Pentecostal no Brasil (1919-2004). Rio de Janeiro: CPAD, 2004, 3v.

MUMFORD, L. A condição de homem: uma análise dos propósitos e fins do desenvolvimento humano. Rio de Janeiro: Editora Globo, 1952.

PROENÇA, W. L. Sindicato de mágicos: uma história cultural da Igreja Universal do Reino de Deus (1977-2007). São Paulo: Editora UNESP, 
2011.

REIS, J. C. História e Teoria. Historicismo, modernidade, temporalidade e verdade. Rio de Janeiro: FGV, 2003.

História da "consciência histórica" Ocidental contemporânea: Hegel, Nietzsche, Ricoeur. Belo Horizonte/MG: Autêntica, 2011.

ROIZ, D. S. Literatura e leituras do milenarismo em Georges Duby (1919-1996). Signum - revista da ABREM, v. 11, n. 2, 2010, p. 109-129.

ROUANET, S. P. As razões do lluminismo. São Paulo: Companhia das Letras, 1987.

SCHAFF, A. História e verdade. Tradução de Maria Paula Duarte. São Paulo: Martins Fontes, 1995.

SOUZA, M. G. Ilustração e História. O pensamento sobre a história no lluminismo francês. SP: Discurso Editorial, 2001.

VOEGELIN, E. Anaminese: da teoria da história e da política. Tradução de Elpídio Mário Dantas Fonseca. São Paulo: É Realizações, 2009.

VOVELLE, M. Ideologias e mentalidades. Tradução de Maria Julia Cottvasser. São Paulo: Brasiliense, 1987.

Edusc, 2000.

Jacobinos e jacobinismo. Bauru/SP:

\section{LAS EXPECTATIVAS ESCATOLÓGICAS EN LA(S) FILOSOFÍA(S) DE LA HISTORIA DE LA IGLESIA ASAMBLEA DE DIOS EN BRASIL}

Resumen: Se estudia el formato de las expectativas escatológicas propagadas por las filosofías de la historia construidas por la Iglesia Asamblea de Dios en Brasil (Ministerio de Belem) entre los años de 1970 y la primera década del siglo XXI.

Palabras clave: Escatología; Filosofía de la Historia; Iglesia Asamblea de Dios. 